\title{
HUBUNGAN PENDIDIKAN DENGAN PENGETAHUAN WANITA USIA SUBUR TENTANG PAP SMEAR DI PONDOK PESANTREN AL HIDAYAH KENDAL NGAWI
}

\author{
Erika MartiningWardani, EppySetiyowati \\ Fakultas Keperawatan dan Kebidanan Universitas Nahdlatul Ulama Surabaya \\ e-mail : erika@unusa.ac.id
}

\begin{abstract}
Abstrak : Kanker leher rahim yang disebabkan oleh Human Papilloma Virus (HPV) merupakan kanker terbanyak penyebab kematian pada wanita. Kanker ini dapat terdeteksi secaradini dengan pemeriksaan pap smear. Tingginya angka kejadian kanker leher rahim disebabkan oleh rendahnya pengetahuan dan kesadaran akan dampak penyakit kanker leher rahim. Rendahnya tingkat pengetahuan diyakini memperburuk kondisi dan diperkirakan akan meningkatkan angka kejadian kanker leher rahim. Tujuan penelitian untuk mengetahui hubungan tingkat pendidikan dengan pengetahun tentang pap smear. Penelitian ini merupakan penelitian analitik Rank Spearmandengan metode cross sectional dengan $\alpha<$ 0,05 . Pengambilan sampel menggunakan teknik accidental sampling yaitu wanita usia subur yang melakukan pemeriksaan pap smear sebanyak 36 orang. Hasil penelitian menunjukkan bahwa sebanyak 19,4 \%berpendidikan SMA dan memiliki pengetahuan cukup $52,8 \%$ tentang pap smeardengan uji statistik menunjukkan bahwa terdapat hubungan antara tingkat pendidikan ( $\rho$ Value $=0,000$ ) dengan pengetahuan tentang pap smear. Semakin tinggi pendidikan semakin baik cara menerima informasi sehingga banyak informasi yang didapat. Pengetahuan baik yang dimiliki oleh wanita usia subur didapatkan melalui interaksi sosial dengan berbagi pengalaman dengan mereka yang pernah melakukan pap smear.Kesimpulan :Persepsi yang baik tentang pencegahan kanker leher rahim berhubungan dengan tindakan pencegahan dengan deteksi dini kanker leher rahim dengan pap smear.
\end{abstract}

Keywords : Pengetahuan, pendidikan, pap smear

\begin{abstract}
Cervical cancer affected by Human Papilloma Virus (HPV) as highly women death cause cancer. It detectable early with pap smear examination. The high rate incidence of cervical cancer caused by lack of knowledge and awareness on the impact of cervical cancer. The lower knowledge level is believed aggravate condition and estimated will increase the incidence of cervical cancer. The objective of this research to recognize correlation of education level and knowledge on pap smear. This research was analytical research Rank Spearman with cross sectional method get $\alpha<0,05$. Sampling done using accidental sampling that were eligible women who undertaking pap smear examination as 36 respondents. The result of this research showed that 19,4\% respondents get high school education and has adequate knowledge about pap smear as 52,8 with statistic test indicate there was correlation among education level $(\rho$ Value $=0,000<\alpha)$ and pap smear knowledge. The higher education the better way to accept the information then many information gained. Well knowledge belong to eligible women gained through social interaction by sharing experiences with them who ever have pap smear. Well perception on cervical cancer correlated to early precaution of cervical cancer with pap smear.
\end{abstract}

Keywords : knowledge, education, pap smear 


\section{PENDAHULUAN}

Kanker leher rahim merupakan masalah kesehatan yang penting bagi wanita di seluruh dunia dan merupakan penyebab kematian utama kanker pada wanita khususnya di negara-negara yang sedang berkembang (Kumalasari dan Andhyanto, 2012).

Kanker leher rahim merupakan penyakit dengan prevalensi urutan ketiga terbanyak pada wanita diseluruh dunia.Kanker leher rahim di Indonesia merupakan penyakit kanker perempuan urutan pertama (Pusdatin, 2015).Prevalensijumlah kanker serviks di Provinsi Jawa Timur sebesar 21.313 penduduk (Pusdatin, 2015). Menurut data dinas kesehatan Kabupaten Ngawi (2014), penderita kanker leher rahim mencapai $2,57 \%$.

Pap smear adalah pemeriksaan mikroskopik terhadap sel-sel yang diperoleh dari asupan serviks.Pap smear dapat mendeteksi sampai $90 \%$ kasus serviks secara akurat dan dengan biaya yang tidak terlalu mahal sehingga angka kematian akibat kanker serviks menurun sampai 50\% (Yohanes, 2007).

Berdasarkan studi pendahuluan yang diambil dari wanita usia subur yang tinggal di sekitar Pondok Pesantren Al Hidayah Kecamatan Kendal Kabupaten Ngawi tahun 2017 di dapatkan hasil, dari 13 WUS yang berkunjung, 9 WUS diantaranya belum tahu tentang pap smear dan 4 WUS lainnya sudah mengerti tentang pap smear.

Upaya menanggulangi kanker leher rahim yang harus dilaksanakan adalah upaya pendidikan kesehatan agar paham pentingnya pemeriksaan dini dan bersedia melaksanakan pemeriksaan ini secara berkala.

Berdasarkan data dan paparan diatas, penulis tertarik untuk mengetahui apakah terdapat hubungan antara tingkat pendidikan wanita usia subur dengan pengetahuan wanita usia subur tentang pap smear di Pondok Pesantren Al
Hidayah Kecamatan Kendal Kabupaten Ngawi.

\section{METODE PENELITIAN}

Penelitian ini merupakan penelitian analitik Rank Spearmandengan metode cross sectional dengan $\alpha<0,05$. Pengambilan sampel menggunakan teknik accidental sampling yaituwanita usia subur yang berkunjung pada saat baksos pemeriksaan pap smear sebanyak 36 orang. Kriteria inklusi pada penelitian ini adalah wanita usia subur yang hadir pada saat baksos yang berpendidikan dasar, menengah dan tinggi. Penelitian dilakukan di Pondok Pesantren Al Hidayah Kendal Ngawi. Penelitian ini dilaksanakan pada tanggal 23- 24 Mei 2017.

\section{HASIL DAN PEMBAHASAN}

\section{Hasil}

a)

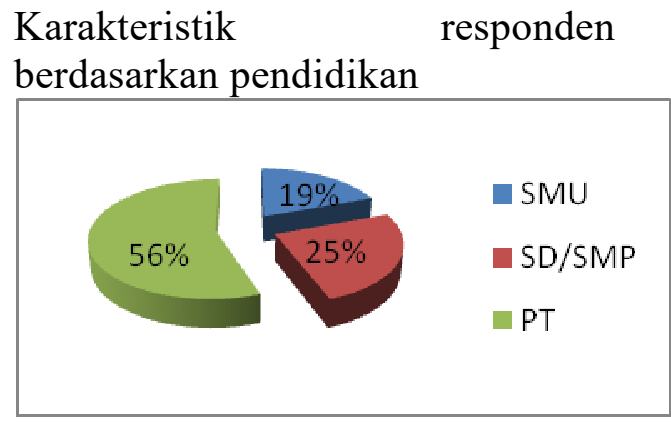

\section{Gambar 1Distribusi Tingkat Pendidikan Wanita Usia Subur}

Berdasarkan gambar 1 sebagian besar wanita usia subur yang berkunjung ke Pondok Pesantren Al Hidayah Ngawi berpendidikan SMA sebanyak 28 orang $(57,1 \%)$.

b) Karaktertistik responden berdasarkan pengetahuan 


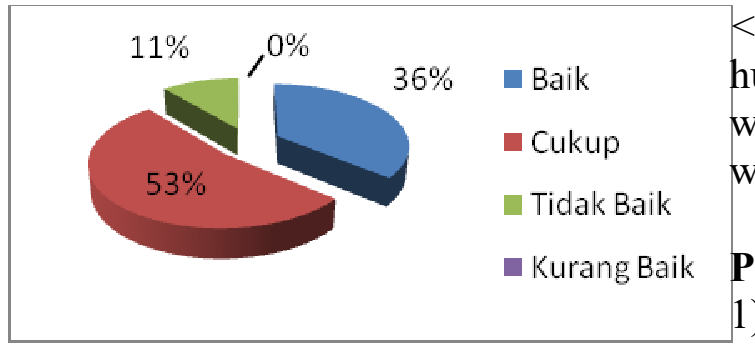

Gambar 2 Diagram Distribusi Tingkat Pengetahuan Wanita UsiaSubur

Berdasarkan gambar diatas Tingkat Pengetahuan Wanita Usia Subur tentang Pap Smear baik yaitu 27 orang ( 55,1\%).

c) Hubungan pendidikan dengan pengetahuan tentang pap smear

Tabulasi silang hubungan antara tingkat pendidikan wanita usia subur dengan pengetahuan wanita usia subur tentang pap smeardapat dilihat sebagai berikut:

Tabel 1 Tabulasi silang hubungan antara tingkat pendidikan dengan pengetahuan wanita usia subur tentangpap smear

\begin{tabular}{cllllr}
\hline Pendidi & \multicolumn{5}{c}{ Pengetahuan } \\
\cline { 2 - 6 } kan & Baik & Cukup & Tidak & Kurang \\
baik & Jumlah & baik & $\mathrm{N}(\%)$ \\
& $\mathrm{N}(\%)$ & $\mathrm{N}(\%)$ & $\mathrm{N}(\%)$ & \\
\hline SD & $3(15)$ & $13(65)$ & $4(20)$ & 0 & $20(100)$ \\
SMP & $3(33,3)$ & $6(66,7)$ & 0 & 0 & $9(100)$ \\
SMA & $7(100)$ & 0 & 0 & 0 & $7(100)$ \\
\hline Jumlah & $13(36,1)$ & $19(52,8)$ & $4(11,1)$ & 0 & $36(100)$ \\
\hline
\end{tabular}

Berdasarkan tabel 1 menunjukkan bahwa dari 36 responden terdapat 20 responden yang pendidikan SD $(65,0 \%)$ memiliki pengetahuan cukup. Dari 9 responden yang berpendidikan SMP sebagian besar $(66,7 \%)$ memiliki pengetahuan cukup. Dari 7 responden yang berpendidikan SMA $(100 \%)$ memiliki pengetahuan baik.

Dari hasil uji Rank Spearman dengan nilai kemaknaan $\alpha=0,05$. didapatkan nilai $\rho=0,000$ yang berarti $\rho$ $<\alpha$ maka $\mathrm{H}_{0}$ ditolak artinya ada hubungan antara tingkat pendidikan wanita usia subur dengan pengetahuan wanita usia subur tentang pap smear.

\section{Pembahasan}

1)

Wanita Usia Subur

Tingkat Pendidikan

Berdasarkan penelitian yang dilakukan di Pondok Pesantren Al Hidayah Kendal Ngawi pada tanggal 23 Mei - 24 Mei 2017 didapatkan hasil responden yang berpendidikan SD sebanyak 55,6 $\%$, SMP sebanyak $25 \%$, berpendidikan SMA sebanyak 19,4 $\%$.

Dari data tersebut, terdapat 20 responden $(55,6 \%)$ berpendidikan SD yaitu jenjang pendidikan formal yang berupa pendidikan dasar hal ini disebabkan oleh letak geografis desa yang terpencil yaitu berada di Kabupaten Ngawi sehingga mempengaruhi wanita usia subur yang berkunjung di Pondok Pesantren Al Hidayah untuk menempuh pendidikan yang cukup rendah yaitu berpendidikan SD. Selain hal itu, keadaan sosial ekonomi yang sebagian besar menengah ke bawah membuat penduduk menganggap pendidikan kurang penting.

Hal ini sesuai dengan pendapat dari Hasbullah (2011), bahwa faktor-faktor yang mempengaruhi tingkat pendidikan seseorang diantaranya ideologi, sosial ekonomi, sosial budaya, perkembangan IPTEK dan psikologi.

2) Pengetahuan Wanita Usia Subur tentang Pap Smear

Berdasarkan penelitian yang dilakukan di di Pondok Pesantren Al Hidayah Kendal Ngawi pada tanggal 23 Mei - 24 Mei 2017 
didapatkan hasil 52,8 \% memiliki pengetahuan cukup, 36,1 \% memiliki pengetahuan baik dan $11,1 \%$ memiliki pengetahuan tidak baik.

Dari data tersebut, 19 responden $\quad(52,8 \quad \%)$ berpengetahuan cukup, hal ini disebabkan karena mereka sudah mengingat kembali (Recall) terhadap suatu yang spesifik dari seluruh bahan yang dipelajari atau rangsangan yang telah diterima dalam hal ini mengenai pap smear(Soekidjo, 2003). Pengetahuan baik yang dimiliki oleh wanita usia subur disebabkan karena mereka mengembangkan dirinya dengan mendapat informasi dari luar misalnya melalui interaksi sosial seperti arisan, pengajian dan pertemuan-pertemuan antar warga, misalnya dengan cara wanita usia subur yang telah melakukan pap smear berbagi pengalaman dengan mereka yang belum pernah melakukan pap smear.

Masih ada wanita usia subur yang memiliki pengetahuan kurang dan tidak baik tentang pap smear bukan berarti mereka tidak pernah mendapatkan informasi mengenai pap smear, terkadang mungkin mereka tidak memperhatikan informasi yang diberikan sehingga pengetahuan mereka ada yang kurang bahkan tidak baik. Akan tetapi banyak pula faktor yang mempengaruhi keberhasilan suatu penyuluhan, apakah itu dari penyuluh, sasaran atau dalam proses penyuluhan itu sendiri (Nasrul, 1998). Misalnya dari cara penyampaian materi dan tata bahasa yang digunakan oleh penyuluh kurang dimengerti oleh sasaran sehingga informasi yang diberikan tidak bisa diterima dengan baik oleh wanita usia subur.
3) Hubungan Tingkat Pendidikan dengan Pengetahuan Wanita Usia Subur tentang Pap Smear

Dari hasil penelitian menunjukkan bahwa semakin tinggi tingkat pendidikan wanita usia subur maka semakin tinggi pula pengetahuan wanita usia subur. Hasil tersebut berdasarkan uji Rank Spearman dengan nilai kemaknaan $\alpha=0,05$ didapatkan nilai $\rho=0,000$ yang berarti $\rho<\alpha$ maka $\mathrm{H}_{0}$ ditolak artinya ada hubungan antara tingkat pendidikan wanita usia subur dengan pengetahuan wanita usia subur tentang pap smear.

$\begin{array}{ccr}\text { Dari } & \text { hasil penelitian } \\ \text { menunjukkan } & \text { bahwa } & \text { semakin }\end{array}$ tinggi tingkat pendidikan wanita usia subur maka semakin tinggi pula pengetahuan wanita usia subur tersebut. Menurut teori semakin tinggi pendidikan semakin baik cara menerima informasi juga akan semakin banyak informasi yang didapat akan semakin tinggi pula pengetahuannya (Soekidjo, 2001).

Tingkat pendidikan seseorang akan mempengaruhi penerimaan dan pemahaman terhadap suatu objek atau materi yang dimanifestasikan dalam bentuk pengetahuan. Semakin tinggi tingkat pendidikan seseorang, akan mempengaruhi tingkat penguasaan terhadap materi yang harus dikuasai sesuai dengan tujuan dan sasaran. Pengetahuan yang adekuat, akan membuat seseorang mampu mengambil keputusan dalam tindakan yang akan dilakukan.

Pendidikan yang dimiliki seseorang dapat mengembangkan kepribadian agar lebih bernilai (Hasbullah, 2011), sehingga wanita usia subur akan mengembangkan dirinya dengan membaca dan mendapat informasi dari luar yang dapat memperbanyak pengetahuan 
dan wawasannya. Wanita usia subur akan mempunyai pandangan dan pengetahuan yang luas juga persepsinya terhadap pentingnya suatu hal.

Dalam hal ini pengetahuan wanita usia subur baik karena wanita usia subur mengembangkan dirinya dengan mendapatkan informasi dari luar misalnya melalui interaksi sosial seperti arisan, pengajian dan pertemuanpertemuan antar warga misalnya dengan cara wanita usia subur yang telah melakukan pap smear berbagi pengalaman dengan mereka yang belum pernah melakukan pap smear.

\section{SIMPULAN}

Ada hubungan antara tingkat pendidikan wanita usia subur dengan pengetahuan wanita usia subur tentang pap smear.

\section{Daftar Pustaka}

Arikunto, Suharsimi. 2010. Prosedur Penelitian Suatu Pendekatan Praktik. Jakarta: Rineka Cipta.

Dr. Amru Sofian, Sp. OG(K). Onk. (2012). Rustam Mochtar Sinopsis Obstetri(Obstetri Fisiologi, Obstetri Patologi) Jilid 1. Edisi 3. Jakarta: EGC.

Gumiarti, dkk. (2002). Hubungan Antara Pendidikan, Umur, Jumlah Anak DanTingkat Pengetahuan Ibu Tentang Perkembangan Motorik Pada Anak Usia 1-3 Tahun (Toddler) di Desa Kumuning Lor Kecamatan Arjasa Kabupaten Jember. Jurnal Kesehatan (The Journal Of Health) Vol. 3 No. 1 Hal 1-54, Mei 2005. Malang: Politeknik Kesehatan Malang.
Hasbullah. (2001). Dasar-Dasar Ilmu Pendidikan. Jakarta: Pustaka Populer Obor.

Ismail, T .(1998). http://www.prodia. co.id/infoterkini/isi_rahim.2005 html accessed on monday, Agustus $7^{\text {th }} 201716.15 \mathrm{pm}$ )

Muchlis, R. (2002). Deteksi Dini Kanker. Jakarta: FKUI.

Nursalam (2014). Metodologi Penelitian Ilmu Keperawatan Pendekatan Praktis.Edisi 3. Jakarta: Salemba Medika.

Nursalam. (2011). Konsep dan Penerapan Metodologi Penelitian IlmuKeperawatan: Pedoman Skripsi, Tesis, dan Instrument Penelitian Keperawatan Edisi 2. Jakarta,SalembaMedika

Setiyaningrum, E, SSI, M. Mkes, M.A. Asuhan Kegawatdaruratan Maternitas (Asuhan Kebidanan Patologi). Jilid 4. IN MEDIA.

Soekidjo, N. 2002. Metodologi Penelitian Kesehatan. Jakarta : PT Rineka Cipta.

Soekidjo, N. 2002. Ilmu Kesehatan Masyarakat. Jakarta : PT Rineka Cipta. 